\title{
Variety of habitats associated with common juniper (Juniperus communis L.) growing in Lithuania
}

\section{Ramūnas Vilčinskas,}

Vitas Marozas ${ }^{2}$,

\section{Lina Jociené $\dot{e}^{1}$}

\section{Eugenija Kupčinskienè $\dot{e}^{1 \star}$}

${ }^{1}$ Vytautas Magnus University,

Vileikos St. 8, LT-44404,

Kaunas, Lithuania

${ }^{2}$ Institute of Environment and Ecology, Aleksandras Stulginskis University, Studenty St. 11, LT-5336, Akademija, Kaunas region, Lithuania
Common juniper (Juniperus communis L.) is an important conifer from the ecological and economical point of view. In some areas of the distribution range, it is a widely studied species. Up till now insufficient attention has been paid to junipers growing in the Baltic countries where it is one of three natural conifers and important forest tree species. Recently, molecular markers-based diversity of Lithuanian populations of J. communis was determined, although related biological and ecological variables remain undisclosed. The present study is aimed at the evaluation of biotic and abiotic environment of J. communis according to plant species composition. Fourteen sites with J. communis were selected in the territory of Lithuania. At each site undergrowth trees and shrubs, herbaceous species, dwarf shrubs, and mosses were recorded and the abundance of each species was evaluated. Abiotic environment characteristics were obtained using Ellenberg's indicator values (EIV) of the plant species neighbouring junipers. In the sites with J. communis, 80 species of herbs and dwarf shrubs belonging to 18 families were registered. The largest variety of herbaceous species and dwarf shrubs (18-22 per site) was registered for sites representing xero-thermophile fringes. Species coverage data recorded in the sites in most cases allowed to group sites according to their habitats. Despite rather small territory of the present survey (latitude $(\mathrm{N})$ $56^{\circ} 07^{\prime}-54^{\circ} 11^{\prime}$, longitude (E) $21^{\circ} 06^{\prime}-26^{\circ} 30^{\prime}$ ), the ranges of indexes for environment factors of juniper sites were rather wide: 6.0-7.3 for light, 3.0-5.8 for temperature, 3.7-5.3 for continentality, 4.2-7.8 for soil moisture, 2.7-7.4 for soil reaction, and 2.7-4.4 for soil nitrogen. Among the sites selected by us, the most contrasting in terms of EIV were locations representing coastal brown dunes covered with natural Scots pine forests and xero-thermophile fringes.

Keywords: conifers, Ellenberg's indicatory values, EIV, habitats, species abundance, herbaceous plants 


\section{INTRODUCTION}

Juniperus species are substantial elements of present-day forests (Garcia et al., 2000; Adams, 2011) and some of them are on the border of extinction (Lima et al., 2010; Rumeu et al., 2011; Silva et al., 2011). This historically old genera is important for providing information about evolution of plants in Late Glacial period (Koller et al., 2005; Li et al., 2011, Veski et al., 2012). Juniperus contains economically valuable species used for medicinal purposes (Muto et al., 2008; Kusari et al., 2009), perfume industry (Lawrence, 1984), flavoring of food and alcoholic beverages (Maarse, 1991; Vichi et al., 2007). These circumstances point out the need of comprehensive knowledge about Juniperus species.

Juniperus communis is widely distributed over the Northern hemisphere, growing in Europe and three other continents. Junipers have been examined by molecular and biochemical markers in various regions of their natural occurrence (Canary Islands, Greece, Germany, UK, Russia, Japan, China, Kazakhstan, Nepal, Ethiopia, Guatemala, Cuba, Mexico, Utah, Texas, etc. (Adams et al., 2003; Adams, 2011). Examination of variables of environment extends information complementary to biological data. Broad geography of this species is inevitably related to various conditions of abiotic and biotic environment. Wide range of temperature, light and continentality conditions are characteristic of this plant (Clifton et al., 1997). It may grow in a wide range of soils of varying acidity, moisture and nutrients (Barkman, 1985; Thomas et al., 2007).

Various juniper-associated habitat types are documented for Europe (Helsinki Commission, 1998; Devillers et al., 2001; Davies et al., 2004; Hill et al., 2004a; 2004b; ILE SAS, 2005a; 2005b; 2006). Due to wide geography, juniper shrubs belong to many associations and even to different classes (Vaccinio-Piceetea, QuercoFagetea, Rhamno-Prunetea and Festuco-Brometea). Most comprehensive diversity studies of European J. communis were performed only in some countries of Western Europe (Rosen,
1982; Barkman, 1985; Van Der Merwe et al., 2000). Species composition in J. communis associations is described fragmentally and concerns only a small part of its distribution range (Barkman, 1985; Thomas et al., 2007). In order to obtain broader knowledge about this species, different areas of its distribution range should be investigated.

Up until now, insufficient attention has been paid to junipers growing in the Baltic countries where it is one out of three naturally growing conifers as important species of forest trees. Near the Baltic Sea, J. communis is represented by two vegetation forms (tree or shrub) and belongs to one (ssp. communis (Syme)) out of four subspecies (ssp. nana (Hook), ssp. hemisphaerica (J. \& C. Presl) Nyman, ssp. depressa (Pursh) Franko; Thomas et al., 2007). Scarce data about junipers is opposite to extensive information collected for Pinus sylvestris and Picea abies of this region (Ozolinčius, 1999; Žvingila et al., 2002; Areškevičienè et al., 2005; Kupčinskienè, 2006; Danusevičius et al., 2015). In Lithuania, the biggest attention has been paid to essential oils of the needles and seeds of J. communis (Butkienè et al., 2006; Labokas, Ložienè, 2013), some aspects of morphology and anatomy were taken into account (Vaitkevičiūtè et al., 2011a; 2011b), and the role of junipers in surface fires in pine forests has been analyzed (Marozas et al., 2007; 2013). Recently, ISSR markers-based molecular diversity of Lithuanian populations of J. communis was determined (Vilcinskas et al., 2016), although related biological and ecological variables remain undisclosed. The present study is aimed at the evaluation of biotic and abiotic environment of the Lithuanian J. communis in relation to the abundance of neighbouring herbaceous plant species.

\section{MATERIALS AND METHODS}

Selection of sites was based on former dendrological and biochemical surveys of Lithuanian junipers (Vaitkevičiūtè et al., 2011a; 2011b; Labokas, Ložiene, 2013). Fourteen locations with Juniperus communis L. were included 
into the study in order to represent habitat variety and to cover distinct parts of Lithuania, although this species is abundant only in the south-eastern part of the country. The study area comprised sites within following geographical ranges: $56^{\circ} 07^{\prime}-54^{\circ} 11^{\prime}$ (North-South) for latitude, $21^{\circ} 06^{\prime}-26^{\circ} 30^{\prime}$ (West-East) for longitude, and $25-187 \mathrm{~m}$ for altitude (Vilcinskas et al., 2016). Climate parameters of population sampling sites were as follows: $7.2-8.8^{\circ} \mathrm{C}$ for annual mean temperature, $12.8-14.0^{\circ} \mathrm{C}$ for vegetation period mean temperature, $632-$ $835 \mathrm{~mm}$ for annual rainfall, and $419-502 \mathrm{~mm}$ for rainfall of vegetation period (climate characteristics were obtained from the meteorological stations closest to the sampling site). Populations were titled according to the location (the number) and the habitat type (the first letter of the habitat code, following the classification of Davies et al., 2004; Fig. 1).

Records of associated species in the sites with J. communis were done within the last decade of June, 2012. For species documentation, $100 \mathrm{~m}^{2}$ plots were used at each site. The composition of species of undergrowth trees and shrubs, herbaceous plants, dwarf shrubs, and mosses

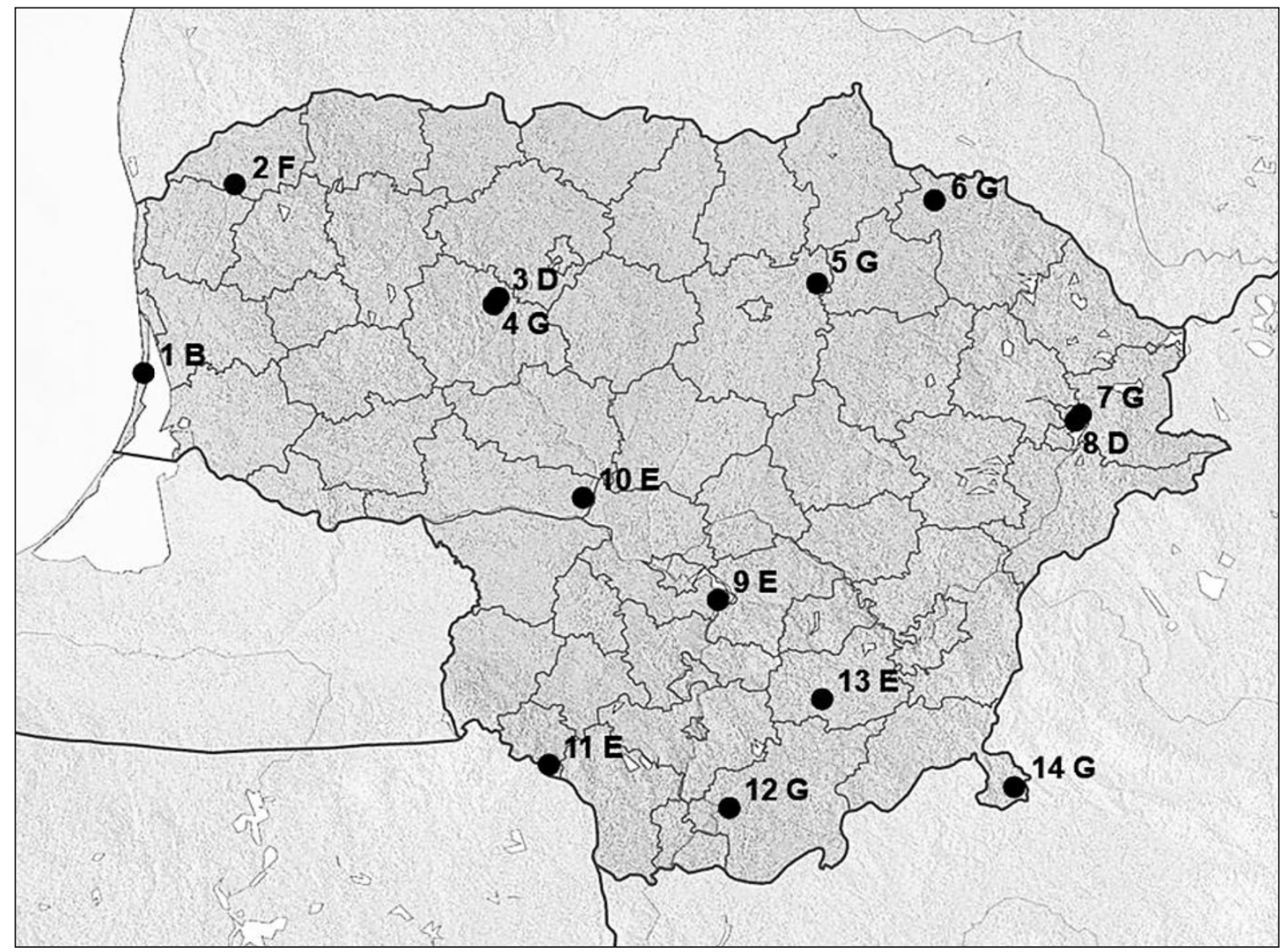

Fig. 1. Study sites of Juniperus communis L. growing in Lithuania. Explanation of site codes:

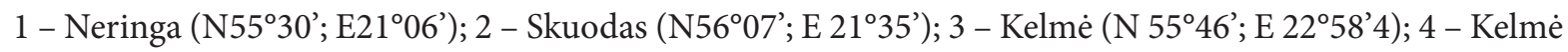

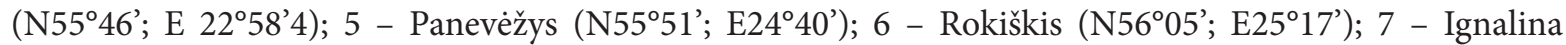

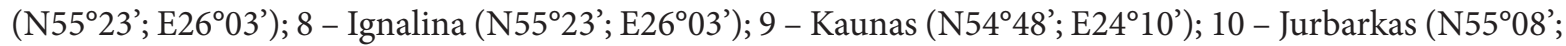

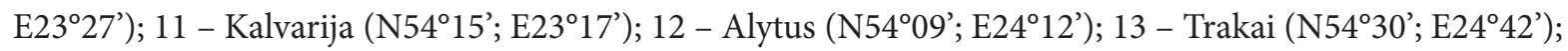
14 - Šalčininkai (N54 $11^{\prime}$; E25 $42^{\prime}$ ). E - xero-thermophile fringes; D - transition mires and quaking bogs; G - subcontinental moss Scots pine forests; F - Juniperus communis shrubs; B - coastal brown dunes covered with natural Scots pine forests 
were recorded and abundance of each species was evaluated by percentage cover as described earlier (Marozas, 2004; 2005). The values of the environment (light, temperature, continentality, soil moisture, reaction and nitrogen) at the sites were estimated using species indicator values (Ellenberg et al., 1991) in proportion to the species percentage cover, applying weighted average method (Jongman et al., 1995) and summarizing separate factor data by STATISTICA v. 7.0 (StatSoft Inc., USA, 2004). Species and sites were evaluated by two-way cluster analyses using PC-ORD 6.0 software (McCune et al., 2011).

\section{RESULTS AND DISCUSSION}

There were differences in plant species number, composition and coverage among the Lithuanian sites with J. communis. Coverage of J. communis was not equal across the sites: this parameter ranged in the interval from $3 \%(7 \mathrm{G})$ to $60 \%$ ( $2 \mathrm{~F}$ ), mean being $18.5 \%$. Coverage by juniper depended on the habitat type, the smallest being for $\mathrm{D}$ (transition mires and quaking bogs) habitat (5\% as a mean) and the highest for $\mathrm{E}$ (xero-thermophile fringes) habitat (36\% as a mean). In half of the sites (the B site and all G sites) 1st stand layer with Pinus sylvestris was characteristic. Scots pine was the prevailing tree in B and in subcontinental moss Scots pine forest ( $G$ habitat) sites, where coverage by pine was 70\% (5 G site was an exception, with pine coverage of $40 \%)$. For two sites (1 B, $7 \mathrm{G}$ ) Betula pendula with $10-15 \%$ coverage was documented.

In the 2nd stand layer Picea abies was found in two sites of subcontinental moss Scots pine forests ( $G$ type habitat). Trees and shrubs of the 2 nd stand layer were registered for all sites, the number of species per site ranged in the interval 3-7. Among 17 species representing this layer, Frangula alnus, Quercus robur, and Sorbus aucuparia were the most common ones for most of the sites, except the E habitat type. Coverage higher than $1 \%$ was characteristic of the following trees: Betula pendula $(15 \%-1 \mathrm{~B}$; $10 \%-7$ G), Picea abies (5\% - 4 G, 7 G), Malus sylvestris $(2 \%-13 \mathrm{E})$, Salix cinerea $(5 \%-8 \mathrm{D}$; $30 \%-3 \mathrm{D})$.

In the sites with J. communis, 80 species of herbs and dwarf shrubs representing 18 families were registered. The species number for a separate family was as follows: Asteraceae - 12, Poaceae - 9, Fabaceae - 8, Rosaceae - 7, Ericaceae - 7, Cyperaceae - 5, Equisetaceae - 3, Plantaginaceae - 3, Apiaceae - 3. Such data show that Dicots are more spread compared to Monocots and agree with the results obtained in some places of Sweden (Rosen, 1982).

Coverage higher than $1 \%$ was characteristic for such herbs and dwarf shrubs as Calluna vulgaris $(5 \%-4 \mathrm{G} ; 20 \%-2 \mathrm{~F})$, Carex lasiocarpa (5\% - $3 \mathrm{D} ; 40 \%-8 \mathrm{D})$, Daucus carota $(5 \%-11 \mathrm{E} ; 3 \%-13 \mathrm{E})$, Deschampsia flexuosa $(2 \%-12$ G; $30 \%-1$ B), Festuca ovina $(5 \%-2$ F, $6 \mathrm{G})$, Filipendula ulmaria (5\% - 3 D), Galium mollugo (3\% - $13 \mathrm{E})$, Melampyrum pratense (5\% - 1 B, 12 G; $10 \%$ - 7 G; 30\% - 6 G), Menyanthes trifoliata $(5 \%-3 \mathrm{D})$, Molinia coerulea $(3 \%-8 \mathrm{D})$, Potentilla palustris $(5 \%-3 \mathrm{D}, 8 \mathrm{D})$, Vaccinium myrtillus (3\% - 12 G; 5\% - 14 G; $10 \%-1 \mathrm{~B} ; 20 \%-4 \mathrm{G}, 7 \mathrm{G})$, Vaccinium vitis-idaea (5\% - 1 B, 6 G, 12 G; $10 \%-4$ G; 40\% - 2 F). Our study is in agreement with the data about other juniper areas where the Ericaceae family species were documented as important undergrowth components of conifer forests with J. communis (Moir, Ludwig, 1979; DeVelice et al., 1986).

Coverage by mosses was characteristic of juniper sites of B, F, and G habitats, the most spread species were Dicranum polysetum $(5 \%-2 \mathrm{~F}$, $4 \mathrm{G}, 6 \mathrm{G}, 7 \mathrm{G})$, Hylocomium splendens $(5 \%-2 \mathrm{~F}$, 4 G; $10 \%$ - 14 G; 20\% - 6 G, 7 G, 12 G), Pleurozium schreberi $(10 \%-5 \mathrm{G} ; 30 \%-4 \mathrm{G}, 7 \mathrm{G}$, 12 G; $40 \%-14$ G; $50 \%-2$ F, 6 G; $60 \%-1$ B), Ptilium crista-castrensis (10\% - 4 G), for D habitat type sites Sphagnum sp. was documented $(10 \%-8 \mathrm{D} ; 50 \%-3 \mathrm{D})$. J. communis demonstrates a wide variety of undergrowth types; species registered in our study coincided in general with the list of main species characteristic of related Lithuanian habitats (Rašomavičius, 2012).

In our study, the biggest variety of herbaceous species and dwarf shrubs was registered for xero-thermophile fringes (E type habitats; 
18-22 per site), the second was transition mires and quaking bogs (D habitat; $13-15$ per site), sites belonging to the other habitats $(\mathrm{B}$, $F$ or $G$ ) were less rich in species (6-12 per site). Our results about the number of species in xero-thermophile fringes (E type habitat) were in agreement with 20-25 differential species registered in East Germany, South Sweden, or Central Netherlands (Barkman, 1985).

Employing two-way cluster analysis for the species coverage data in the sites, all species neighbouring junipers were classified into two main clusters (Fig. 2). One, the most distinct cluster comprised 40 species (their list is provided in Fig. 2 title explanations), the second cluster consisted of two subdivisions: 2 a contained 34 species, and $2 \mathrm{~b}$ contained 28 species. In respect to species composition, all juniper sites were also subdivided into two branches: one of them (I) comprised sites of transition mires and quaking bogs (D habitat) as the most distinct habitat, which corresponded to the first cluster of the species. The second site cluster (II) consisted of two subclusters: one of them (II-1) contained the sites belonging to xero-thermophile fringes (E habitat) and one site of subcontinental moss Scots pine forests (5 G), the other subcluster (II-2) formed a branched structure. The branches have subdivided sites according to their habitats into two groups (II$2 \mathrm{a}$ and II-2b), the most distinct one was site representing Juniperus communis shrubs (F habitat; II-2a). In the II-2b cluster the branches of the next order separated site of

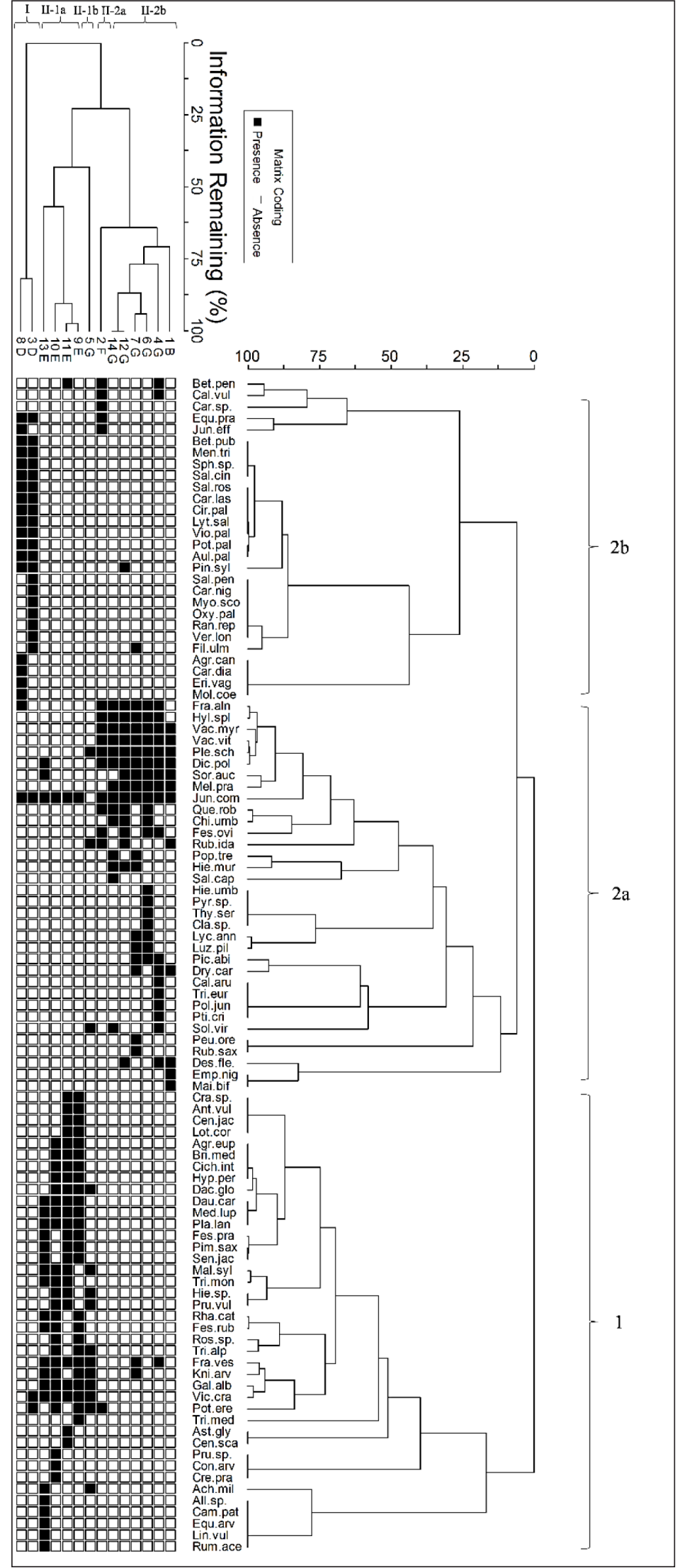

Fig. 2. The species diversity of trees, shrubs, herbs and mosses in sites with J. communis. 
Right side cladogram.

Cluster 1: Cra.sp - Crataegus sp.; Ant.vul - Anthyllis vulneraria L.; Cen.jac - Centaurea jacea L.; Lot.cor - Lotus corniculatus L.; Agr.eur - Agrimonia eupatoria L.; Bri.med - Briza media L.; Cich.int - Cichorium intybus L.; Hyp.per - Hypericum perforatum L.; Dac.glo - Dactylis glomerata L.; Dau.car - Daucus carota L.; Med.lup - Medicago lupulina L.; Pla.lan - Plantago lanceolata L.; Fes.pra - Festuca pratensis Huds; Pim. sax - Pimpinella saxifraga (L.) Moench.; Sen.jac - Senecio jacobaea L.; Mal.syl - Malus sylvestris (L.) Mill.; Tri.mon - Trifolium montanum L.; Hie.sp - Hieracium sp.; Pru.vul - Prunella vulgaris L.; Rha.cat - Rhamnus catharticus L.; Fes.rub - Festuca rubra L.; Ros.sp - Rosa sp.; Tri.alp - Trifolium alpestre L.; Fra.ves - Fragaria vesca L.; Kni.arv - Knautia arvensis (L.) Coult; Gal.alb - Galium album Mill.; Vic.cra - Vicia cracca L.; Pot. ere - Potentilla erecta (L.) Rausch.; Tri.med - Trifolium medium L.; Ast.gly - Astragalus glycyphyllos L.; Cen. sca - Centaurea scabiosa L.; Pru.sp - Prunella vulgaris L.; Con.arv - Convolvulus arvense L.; Cre.pra - Crepis praemorsa (L.) Taush; Ach.mill - Achillea millefolium L.; All.sp - Allium sp.; Cam.pat - Campanula patula L.; Equ.arv - Equisetum arvense L.; Lin.vul - Linaria vulgaris (L.) Mill.; Rum.ace - Rumex acetosa L.

Cluster 2a: Fra.aln - Frangula alnus Mill.; Hyl.spl - Hylocomium splendens (Hedw.) B.S.G.; Vac.myr - Vaccinium myrtillus L.; Vac.vit - Vaccinium vitis-idaea L.; Ple.sch - Pleurozium schreberi (Brid.) Mitt.; Dic. pol - Dicranum polysetum Sw.; Sor.auc - Sorbus aucuparia L.; Mel.pra - Melampyrum pratense L.; Jun. com - Juniperus communis L.; Que.rob - Quercus robur L.; Chi.umb - Chimaphila umbellata (L.) W. Bart.; Fes.ovi - Festuca ovina L.; Rub.ida - Rubus idaeus L.; Pop.tre - Populus tremula L.; Hie.mur - Hieracium murorum L.; Sal.cap - Salix caprea L.; Hie.umb - Hieracium umbellatum L.; Pyr.sp - Pyrola sp.; Thy.ser - Thymus serpyllum L.; Cla.sp - Cladonia sp.; Lyc.ann - Lycopodium annotinum L.; Luz.pil - Luzula pilosa (L.) Willd; Pic.abi - Picea abies (L.) Karst.; Dry.car - Dryopteris carthusiana (Vill.) H.P. Fuchs; Cal.aru - Calamagrostis arundinacea (L.) Roth.; Tri.eur - Trientalis europaea L.; Pol.jun - Polytrichum juniperinum Hedw.; Pti. cri - Ptilium crista-castrensis (Hedw.) De Not.; Sol.vir - Solidago virgaurea L.; Peu.ore - Peucedanum oreoselinum L. Moench.; Rub.sax - Rubus saxatilis L.; Des.fle - Deschampsia flexuosa (L.) Trin.; Emp.nig - Empetrum nigrum L.; Mai.bif - Maianthemum bifolium (L.) F.W. Schm.

Cluster 2b: Bet.pen - Betula pendula Roth; Cal.vul - Calluna vulgaris (L.) Hull; Car.sp - Carex sp.; Equ. pra - Equisetum pratense Ehrh.; Jun.eff - Juncus effusus L.; Bet.pub - Betula pubescens Ehrh.; Men.tri - Menyanthes trifoliata L.; Sph.sp - Sphagnum sp.; Sal.cin - Salix cinerea L.; Sal.ros - Salix rosmarinifolia L.; Car. las - Carex lasiocarpa Ehrh.; Cir.pal - Circium palustre (L.) Scop.; Lyt.sal - Lythrum salicaria L.; Vio.pal - Viola palustris L.; Pot.pal - Potentilla palustris (L) Scop.; Aul.pal - Aulacomnium palustre (Hedw.) Schwaegr.; Pin.syl - Pinus sylvestris L.; Sal.pen - Salix pentandra L.; Car.nig - Carex nigra (L.) Reichard; Myo.sco - Myosotis scorpioides L.; Oxy.pal - Oxycoccus palustris Pers.; Ran.rep - Ranunculus repens L.; Ver.lon - Veronica longifolia L.; Fil.ulm - Filipendula ulmaria (L.) Maxim.; Agr.can - Agrostis canina L.; Car.dia - Carex diandra Schrank; Eri.vag - Eriophorum vaginatum L.; Mol.coe - Molinia coerulea (L.) Moench.

Explanation of the site codes in the top side cladogram is provided in Figure 1.

B habitat from 5 sites of subcontinental moss Scots pine forests (G habitat). Hereby, the coverage data of herbs and dwarf shrubs recorded for the sites allowed, in most cases, to group the sites according to their habitats, the only exception being one site of subcontinental moss Scots pine forests ( $5 \mathrm{G}$ ).

Composition of plant species is considered a good indicator of habitat edaphic and aerial properties, which are frequently quantified using species indicator values (Ellenberg et al.,
1991). For our study sites, light index range was an in the interval 6.0-7.3, and, according to this value, it was an obvious separation of sites into two groups - transition mires and quaking bogs (D habitat), xero-thermophile fringes (E habitat), and remainders (Fig. 3). Light index for all sites was higher than the middle value (5) and reflected a higher demand of J. communis for irradiation, despite some sites being forested areas. It shows that the forest sites of J. communis selected by us 


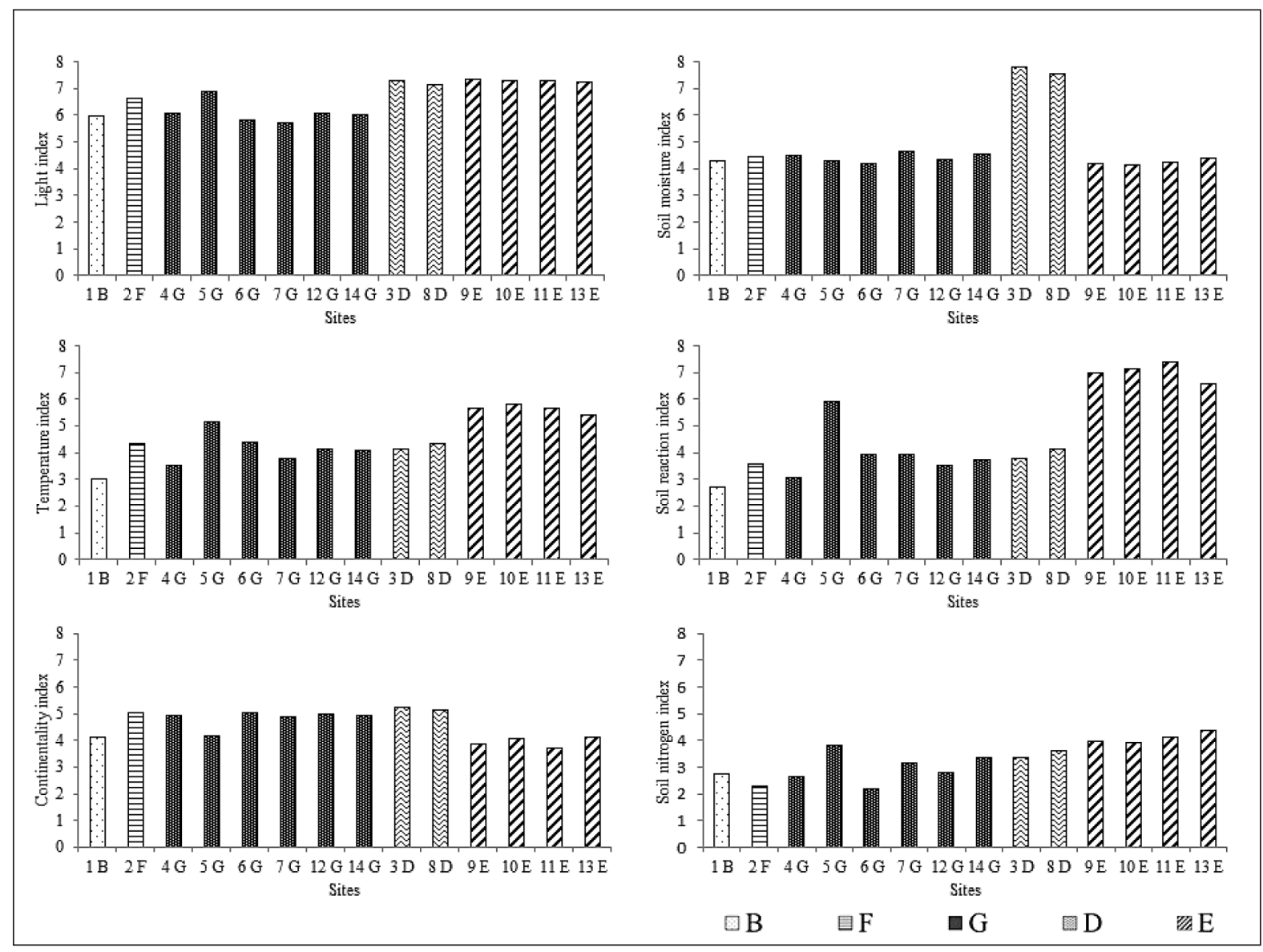

Fig. 3. Ellenberg (1991) indicatory values of herbaceous species in sites with J. communis.

B - coastal brown dunes covered with natural Scots pine forests; F - J. communis shrubs; D - transition mires and quaking bogs; $\mathrm{G}$ - subcontinental moss Scots pine forests; $\mathrm{E}$ - xero-thermophile fringes

were in forest gaps. It is in agreement with what is known from other surveys (Thomas et al., 2007). The temperature index varied in a broader interval, 3.0-5.8, compared to the light parameter. In respect to temperature, the warmest sites belonged to the opened area habitat xero-thermophile fringes (E), the differences of the habitat of other type were not expressed. The continentality index varied in the interval of 3.7-5.3 and neither showed relation to the geography, nor to the habitat type of the sites. For our study sites, the soil moisture index ranged between 4.2 and 7.8, separating sites of transition mires and quaking bogs (D habitat) from remainders. Moist summers are needed to enable juniper seedlings to develop, and an extreme drought during one summer may cause dieback of junipers (Rosen, Van Der
Maarel, 2000). The ranges of soil reaction index for Lithuanian junipers were also very wide, fitting into the interval of 2.7 and 7.4. The most distinct were sites belonging to calcareous habitat xero-thermophile fringes (E habitat). According to this parameter, sites were subdivided into two groups ( $5 \mathrm{G}$ site was an exception). In another study of juniper-related sites (the set of sites was not the same as in our study) of Lithuania, chemical analyses of the soil $\mathrm{pH}$ revealed a different interval - 4.1-7.7 (Vaičiulyte, Ložienè, 2013). The soil nitrogen index showed low fertility of soils, for all sites; this index was lower than the middle value (5) and ranged in the interval 2.7-4.4. Ellenberg et al. (1991) data indicates a wide range requirement for nitrogen. Protected by EUNIS, the habitat of Juniperus communis shrubs (site $2 \mathrm{~F}$ ) did not have any 
marginal values of abiotic environment. For junipers of this site the highest polymorphism was defined employing some molecular markers (Vilcinskas et al., 2016). Among the juniper sites selected by us the most contrasting ones according to Ellenberg indicatory values of herbaceous species was the site representing coastal brown dunes covered with natural Scots pine forests (B habitat), and the sites of xerothermophile fringes (E habitat).

Despite the rather small territory of Lithuania, our data are in support to other studies which indicate that junipers occur in a wide range of climates and on a wide variety of soils (Barkman, 1985; Rosen, Van Der Maarel, 2000), including acid and calcareous sands, loam, both wet and dry habitats.

\section{CONCLUSIONS}

1. The coverage data of herbs and dwarf shrubs recorded for the sites with junipers in most cases allowed clusteringof the sites according to their habitats.

2. Among the juniper sites selected by us, the most contrasting ones, according to Ellenberg indicatory values of herbaceous and wooden species, were habitats entitled as coastal brown dunes covered with natural Scots pine forests (B) and xero-thermophile fringes (E).

3. For junipers from the habitat protected by EUNIS and entitled Juniperus communis shrubs, no marginal values of abiotic environment were documented despite the fact that a former study revealed the highest polymorphism by some molecular markers.

\section{ACKNOWLEDGEMENTS}

We are grateful to people who suggested the sampling sites or technically participated in the research: Dr. K. Ložienè (Nature Research Centre, Vilnius); foresters from Forest State enterprises C. Mikulskas (Kalvarija), S. Gliaudys (Vainagiai), and A. Rinkevičius (Pandèlis).

Received 2 February 2016 Accepted 22 September 2016

\section{References}

1. Adams RP, Schwarzbach AE, Pandey RN. The concordance of terpenoid, ISSR and RAPD markers, and ITS sequence data sets among genotypes: an example from Juniperus. Biochem Syst Ecol. 2003; 31(4): 375-87.

2. Adams RP. Junipers of the World: The Genus Juniperus. 3rd ed. Trafford Publishing Company, Victoria, BC; 2011.

3. Areškevičienè R, Žvingila D, Gabrilavičius R, Kuusienè $S$. The estimation of genetic diversity within and between Lithuanian populations of Norway spruce (Picea abies (L.) Karst.) by using RAPD. Balt For. 2005; 11: 2-8.

4. Barkman JJ. Geographical variation in associations of juniper scrub in the Central European plain. Vegetatio. 1985; 59: 67-71.

5. Butkienè R, Nivinskienė O, Mockutė D. Differences in the essential oils of the leaves (needles), unripe and ripe berries of Juniperus communis L. growing wild in Vilnius district (Lithuania). J Essent Oil Res. 2006; 18: 489-94.

6. Clifton SJ, Ward LK, Ranner DS. The status of juniper Juniperus communis L. in North-East England. Biol Conserv. 1997; 79: 67-77.

7. Danusevičius D, Kavaliauskas D, Kerpauskaitė V, Fussi B, Konnert M. DNA markers reveal a genetic association between a sea-side Lithuanian and Bavarian Scots pine population. Silvae Genet; accepted paper.

8. Davies CE, Moss D, Hill MO. EUNIS Habitat Classification revised 2004. European Topic Centre on Nature Protection and Biodiversity, Paris; 2004.

9. DeVelice RL, Ludwig JA, Moir WH, Ronco F. A classification of forest habitat types of northern New Mexico and southern Colorado. Rocky Mountain Forest and Range Experiment Station, Fort Collins, Colo. USDA Forest Service General Technical Report RM-131, 1986; 59 p.

10. Devillers P, Devillers-Terschuren J, Vander Linden C. Palaearctic Habitats. PHYSIS Data Base, 1996, last updated 1999. Royal Belgian 
Institute of Natural Sciences website, www. naturalsciences.be/cb [Last updated 2001].

11. Ellenberg H, Weber HE, Wirth V, Werner W, Paulien D. Zeigerwerte von Pflanzen in Mitteleuropa. Scr Geobot. 1991; 18: 1-258. German.

12. Garcia D, Zamora R, Gomez JM, Jordano P, Hodar JA. Geographical variation in seed production, predation and abortion in Juniperus communis throughout its range in Europe. J Ecol. 2000; 88: 436-446.

13. Helsinki Commission. Red List of Marine and Coastal Biotopes and Biotopes Complexes of the Baltic Sea, Belt Sea and Kattegat. Balt Sea Environ Proc, 1998; 75 p.

14. Hill MO, Moss D, Davies CE. Revision of habitat descriptions originating from Devillers et al. (2001). European Topic Centre on Nature Protection and Biodiversity, Paris; 2004a.

15. Hill MO, Moss D, Davies CE. EUNIS habitat classification descriptions. European Topic Centre on Nature Protection and Biodiversity, Paris; 2004b.

16. ILE SAS. Revision of descriptions of terrestrial habitats. Institute of Landscape Ecology Slovak Academy of Sciences; 2005a.

17. ILE SAS. Revision of habitat descriptions originating from Devillers et al. (2001). Institute of Landscape Ecology Slovak Academy of Sciences; 2005b.

18. ILE SAS. Revision of habitat descriptions originating from ILE SAS (2005). Institute of Landscape Ecology Slovak Academy of Sciences; 2006.

19. Jongman RHG, Ter Braak CJF, van Tongeren OFR. Data analysis in community and landscape ecology. Cambridge University Press, New York; 1995.

20. Koller B, Schmitt JM, Tischendorf G. Cellular fine structures and histochemical reactions in the tissue of a cypress twig preserved in Baltic amber. P Roy Soc B-Biol Sci. 2005; 272: $121-6$.
21. Kupčinskienė E. Latent injuries of Scots pine (Pinus sylvestris L.) under influence of local pollution. Monograph, Lutute, Kaunas; 2006.

22. Kusari S, Lamshoft M, Spiteller M. Aspergillus fumigatus Fresenius, an endophytic fungus from Juniperus communis L. Horstmann as a novel source of the anticancer pro-drug deoxypodophyllotoxin. J Appl Microbiol. 2009; 107(3): 1019-30.

23. Labokas J, Ložienė K. Variation of essential oil yield and relative amounts of enantiomers of $\alpha$-pinene in leaves and unripe cones of $J u$ niperus communis L. growing wild in Lithuania. J Essent Oil Res. 2013; 25: 244-50.

24. Lawrence BM. Progress in essential oils. Perfum Flavor. 1984; 9: 37-8.

25. Li Z, Zhang Q, Liu J, Kallman T, Lascoux M. The Pleistocene demography of an alpine juniper of the Qinghai-Tibetan Plateau: tabula rasa, cryptic refugia or something else? J Biogeogr. 2011; 38(1): 31-43.

26. Lima AS, Trindade H, Figueiredo AC, Barroso JG, Pedro LG. Volatile and molecular analysis of Juniperus brevifolia (Seub) Antoine, an Azorean endemic species. Biochem Syst Ecol. 2010; 38(4): 621-9.

27. Maarse $\mathrm{H}$. Volatile compounds in foods and beverages. Marcel Dekker, New York; 1991. p. 79-89.

28. Marozas V. Diversity of lime forest in the different regions of Lithuania. Acta Biol Univ Daugavpiliensis. 2004; 4(1): 47-52.

29. Marozas V. Early succession of ground vegetation after clear-cuttings in spruce forests in a boreonemoral zone, Lithuania. Acta Biol Univ Daugavpiliensis. 2005; 5(2): 127-36.

30. Marozas V, Racinskas J, Bartkevicius E. Dynamics of ground vegetation after surface fires in hemiboreal Pinus sylvestris forests. Forest Ecol Manag. 2007; 250: 47-55.

31. Marozas V. Ground vegetation development after surface fire in Scots pine forest. Rural Development; 2013. p. 355-8. 
32. McCune B, Mefford MJ. PC-ORD. Multivariate analysis of Ecological Data. Version 6.0 MjM Software, Gleneden Beach, Oregon, USA; 2011.

33. Moir WH, Ludwig JA. A classification of spruce-fir and mixed conifer habitat types of Arizona and New Mexico. Rocky Mountain Forest and Range Experiment Station, Fort Collins, Colo. USDA Forest Service Research Paper RM-207; 1979. 47 p.

34. Muto N, Tomokuni T, Haramoto M, Tatemoto $\mathrm{H}$, Nakanishi T, Inatomi Y, Murata $\mathrm{H}$, Inada A. Isolation of apoptosis and differentiation-inducing substances toward human promyelocytic leukemia HL-60 cells from leaves of Juniperus taxifolia. Biosci Biotechnol Biochem. 2008; 72(2): 477-84.

35. Ozolinčius R. (ed.). Monitoring of forest ecosystems in Lithuania. Lutute, Kaunas; 1999. p. 310 .

36. Rašomavičius V, editor. [Manual for Inventory of EU Importance Natural Habitats]. EB svarbos natūralių buveinių inventorizavimo vadovas, Gamtos tyrimų centras, Vilnius. 2012. Lithuanian.

37. Rosen E. Vegetation development and sheep grazing in limestone grasslands of south Gland, Sweden. Acta Phytogeogr Suec. 72. Uppsala; 1982. $104 \mathrm{p}$.

38. Rosen E, Van Der Maarel E. Restoration of alvar vegetation on Oland, Sweden. Appl Veg Sci. 2000; 3: 65-72.

39. Rumeu B, Caujape-Castells J, Blanco-Pastor JL, Jaen-Molina R, Nogales M, Elias RB, Vargas P. The colonization history of Juniperus brevifolia (Cupressaceae) in the Azores Islands. PLoS ONE. 2011; 6(11): e27697.

40. Silva L, Elias RB, Moura M, Meimberg H, Dias E. Genetic variability and differentiation among populations of the Azorean endemic gymnosperm Juniperus brevifolia: Baseline Information for a Conservation and Restoration Perspective. Biochem Genet. 2011; 49(11-12): 715-34.
41. Thomas PA, El-Barghathi M, Polwart A. Biological Flora of British Isles: Juniperus communis L. J Ecol. 2007; 95: 1404-40.

42. Vaičiulytė V, Ložienè K. Variation of chemical and morphological characters of leaves and unripe cones in Juniperus communis. Bot Lith. 2013; 19(1): 37-47.

43. Vaitkevičiūtè R, Brazaitis G, Šepetienè J, Žalkauskas R. Cross valuation of juniper formation - recreational and ecological viewpoints. In: Rural development 2011: The 5th International Scientific Conference; 2011 Nov 24-25; Aleksandras Stulginskis University, Akademija, Lithuania; 2011a. p. 156-60.

44. Vaitkevičiūtè R, Brazaitis G, Šepetienè J. Dendrological and recreational values of Arlaviškès juniper formation. Acta Biol Univ Daugavpiliensis. 2011b; 11(2): 126-33.

45. Van Der Merwe M, Winfield MO, Arnold GM, Parker JS. Spatial and temporal aspects of the genetic structure of Juniperus communis populations. Mol Ecol. 2000; 9: 379-86.

46. Veski S, Amon L, Heinsalu A, Reitalu T, Saarse L, Stivrins N, Vassiljev J. Lateglacial vegetation dynamics in the eastern Baltic region between 14,500 and $11,400 \mathrm{cal}$ yr BP: A complete record since the Bolling (GI-1e) to the Holocene. Quat Sci Rev. 2012; 40: 39-53.

47. Vichi S, Riu-Aumatell M, Mora-Pons M, Guadayol JM, Buxaderas S, Lopez-Tamames E. HS-SPME coupled to GC/MS for quality control of Juniperus communis L. berries used for gin aromatization. Food Chem. 2007; 105: 1748-54.

48. Vilcinskas R, Jociene L, Marozas V, Paulauskas A, Kupcinskiene E. Genetic diversity of Lithuanian populations of Juniperus communis $\mathrm{L}$. in relation to abiotic and biotic factors. Dendrobiology, 76: 61-71.

49. Žvingila D, Verbylaitè R, Abraitis R, Kuusienè S, Ozolinčius R. Assessment of genetic diversity in plus tree clones of Pinus sylvestris L. using RAPD markers. Balt. For. 2002; 8: 2-7. 


\section{Ramūnas Vilčinskas, Vitas Marozas, Lina} Jocienė, Eugenija Kupčinskienè

\section{LIETUVOS PAPRASTOJO KADAGIO (JUNIPE- RUS COMMUNIS L.) BUVEINIŲ IVAIROVE்}

\section{Santrauka}

Paprastasis kadagys (Juniperus communis L.) ekologiniu ir ekonominiu požiūriu yra svarbi spygliuočiu rūšis, išsamiai išnagrinèta kai kuriose arealo srityse. Rytų Baltijos šalių kadagiams, kaip vienai iš trijų natūraliai augančių spygliuočių rūšių, iki šiol skirta nepakankamai dèmesio. Pastaruoju metu J. communis Lietuvos populiacijos ịvertintos pagal kai kuriuos molekulinius žymenis, tačiau genetiniai duomenys išlieka nesusieti su kitomis biologinèmis, ypač ekologinèmis, savybėmis. Tyrimų tikslas buvo ịvertinti Lietuvos kadagiu biotinę ir abiotinę aplinką pagal augančių pomiškio ir trako, krūmokšnių, žolinių augalų ir samanų rūšiu ịvairovę ir gausą. Lietuvoje buvo parinkta 14 vietovių su kadagiais. Abiotinès aplinkos savybès buvo nustatytos pagal augalų rūšių, augančių kartu su kadagiu, Elenbergo indikatorines vertes (EIV). Vietovèse, kuriose auga kadagiai, buvo aptikta 18-os šeimų 80 rūšių žolinių augalų ir krūmokšnių. Didžiausia žolinių augalų îvairove rasta šlaitų pievose (18-22 rūšys). Remiantis rūšių gausa, vietovès su kadagiais sugrupuotos pagal buveinių tipą. Nors mūsų darbe nagrinèjama gana maža teritorija (š. platuma $56^{\circ} 07^{\prime}-54^{\circ} 11^{\prime}$, rytų ilguma $\left.21^{\circ} 06^{\prime}-26^{\circ} 30^{\prime}\right)$, aplinkos indeksai vietovèse su kadagiais svyravo gana plačiose ribose: šviesos $-6,0-7,3$, temperatūros - 3,0-5,8, žemyniškumo - 3,7-5,3, dirvožemio drègnumo - 4,2-7,8, dirvožemio rūgštumo - 2,7-7,4, dirvožemio azoto - 2,7-4,4. Pagal EIV, labiausiai išsiskyrẻ šlaitų pievos ir kopų pušynai.

Raktažodžiai: spygliuočiai, Elenbergo indikatorinès vertès (EIV), buveinès, rūšių gausa, žoliniai augalai 